\title{
Surgical management of cystic adenomyosis. Why the laparoscopic approach is preferable?
}

\author{
G. CALAGNA ${ }^{1}$, G. MISSERI ${ }^{1}$, R. GRANESE ${ }^{2}$, A. DI SPIEZIO SARDO ${ }^{3}$, A. VASSILIADIS ${ }^{1}$, \\ A. SVELATO ${ }^{1}$, A. PERINO ${ }^{1}$, G. CUCINELLA ${ }^{1}$
}

SUMMARY: Surgical management of cystic adenomyosis. Why the laparoscopic approach is preferable?

G. Calagna, G. Misseri, R. Granese, A. Di Spiezio Sardo, A. Vassiliadis, A. Svelato, A. Perino, G. Cucinella

Aim. To evaluate the efficacy and safety of laparoscopic surgical management of cystic adenomyosis, a rare cause of severe dysmenorrhea with poor response to medical therapy.

Method. An electronic search concerning the laparoscopic treatment of cystic adenomyosis is carried out, using following key words: "adenomyotic cyst", "cystic adenomyosis" and "laparoscopy". We selected only the papers that described one or more cases of cystic adenomyosis treated by laparoscopic surgery.

Results. Ten studies were included into the review. Mean patients age was 21.9 years. Severe dysmenorrhea was the symptom reported in all cases. The mean diameter of the cystic mass was $32 \mathrm{~mm}$ (ranging from 20 to $50 \mathrm{~mm}$ ). In all selected cases, authors performed the cyst excision using laparoscopic approach. Laparoscopic cystectomy resulted in a significant reduction in symptoms. There is not recurrence of disease and severe dysmenorrhea during the follow-up period.

Conclusion. In cases of cystic adenomyosis affecting patients in fertile age, conservative treatment is mandatory. Laparoscopic cystectomy should be preferred, for its minimally invasive approach and the excellent medium-term results.

KEY WORDS: Adenomyotic cyst - Cystic adenomyosis - Adenomyosis - Laparoscopy.

Cisti adenomiosica - Adenomiosi cistica - Adenomiosi - Laparoscopia.

1 UOC Obstetrics and Gynecology, University Hospital "P. Giaccone", Palermo

RIASSUNTO: Trattamento chirurgico della cisti adenomiosica. Perché è preferibile l’approccio laparoscopico?

G. Calagna, G. Misseri, R. Granese, A. Di Spiezio Sardo, A. Vassiliadis, A. Svelato, A. Perino, G. Cucinella

Obiettivi. L'obiettivo primario della nostra ricerca è quello di valutare l'efficacia e la sicurezza del trattamento chirurgico laparoscopico nelle pazienti affette da adenomiosi cistica, rara causa di dismenorrea severa, caratterizzata dalla scarsa responsività al trattamento farmacologico.

Metodi. La ricerca computerizzata è stata condotta utilizzando le seguenti parole chiave: "cisti adenomiotica", "adenomiosi cistica", "laparoscopia". Abbiamo esaminato gli studi precedentemente pubblicati sull'adenomiosi cistica, selezionando solo gli articoli che descrivevano uno o più casi trattati chirurgicamente per via laparoscopica.

Risultati. Solo dieci studi sono stati inclusi nella nostra revisione. L'età media delle pazienti è di 21.9 anni. La dismenorrea severa è il sintomo più comunemente riferito. Il diametro medio della lesione cistica uterina è di $32 \mathrm{~mm}$ (range compreso tra 20 e $50 \mathrm{~mm}$ ). In tutti i casi selezionati, gli Autori hanno effettuato il trattamento escissionale della lesione per via laparoscopica. La cistectomia laparoscopica ha portato alla significativa riduzione della sintomatologia. Inoltre, durante il periodo di follow-up non si è presentata recidiva di patologia, né sintomatica.

Conclusioni. Il trattamento chirurgico conservativo si impone qualora l'adenomiosi cistica venga diagnosticata in giovani pazienti in età riproduttiva. In considerazione dell'approccio mini-invasivo e gli ottimi risultati a medio termine, la cistectomia laparoscopica va considerato il trattamento chirurgico di elezione. 


\section{Introduction}

Adenomyosis is a benign gynecological disease characterized by the presence of ectopic endometrial glands and stroma within the myometrium, with adjacent smooth muscle hyperplasia. It is typically diagnosed in parous women and is thought to affect $1 \%$ of women, typically diagnosed in the $4^{\text {th }}$ and $5^{\text {th }}$ decades of life $(1,2)$.

The diffuse form, characterized by the presence of blood-filled cystic spaces, $<5 \mathrm{~mm}$ in greatest diameter $(3,4)$, is typically diagnosed in multiparous premenopausal women and is present in up to $20 \%$ of hysterectomy specimens (5). Focal adenomyosis rarely occurs. It is defined as a circumscribed nodule, also known as adenomyoma or cystic adenomyosis (6), that presents a cystic aspect.

This cystic variant is a rare histopathologic finding and, based on the patient's age at symptom onset, can be classified into adult and juvenile type (3). In juvenile patients, clinical findings are not specific and early presentation of symptoms can be misleading. Differential diagnosis includes primary dysmenorrhea, ovarian endometriomas, degenerative fibroids and bicornuate uterus with non-communicating uterine horn (5). Diagnostic criteria are considered: cystic lesion $1 \mathrm{~cm}$ or greater in diameter, independent of the uterine endometrial cavity, covered by hypertrophic myometrium and associated severe dysmenorrheal (7).

Although rare, cystic adenomyosis is often challenging to manage and requires targeted therapeutic interventions. Medical therapies are usually ineffective and surgery is the preferential option (1). Recent evidence considers laparoscopic cystectomy as the most effective treatment, improving symptoms with a minimally invasive approach (8).

A review of the medical literature on laparoscopic surgical management of cystic adenomyosis has been carried out, with the aim of evaluating the efficacy and safety of this surgical approach.

\section{Materials and methods}

A computerized search of PubMed/Medline, EMBASE, Google Scholar databases to gather information on surgical treatment of cystic adenomyosis was performed, using the key words "adenomyotic cyst", "cystic adenomyosis" and "laparoscopy". All Englishlanguage articles were retrieved. The reference sections in relevant articles were also examined for eligible studies.
Only papers that described one or more cases of cystic adenomyosis treated by laparoscopic surgery were selected. Studies that did not contain the description of surgical procedures and histologic findings were not revised and were thus excluded from this review. Patient variables recorded were as follows: demographic and clinical pre-operative data, eventual medical therapy, surgical procedure, clinical and/or reproductive outcomes. Reproductive outcome was recorded in terms of the number of conceptions, miscarriages and/or deliveries. Moreover, when reported by authors, data on operative time, intraoperative blood loss and hospital stay was evaluated.

\section{Results}

Following selection criteria, only 10 studies were included in the review. Among these, 7 were single case reports and 4 were reviews of multiple cases (ranging from 2 to 9 cases). Main data of the selected studies are shown in Table 1.

Mean patient age was 21.9 years (range from 15 to 27 years). Severe dysmenorrhea was the symptom reported in all cases. In most cases $(95.4 \%)$, authors noted the administration of one or more pre-operative medical therapies, that were ineffective both on the lesion and on symptomatology. There was some variability in the terms used to define the reported pathology: cystic adenomyoma (1,9-11), cystic adenomyosis (5) and juvenile cystic adenomyosis ( $J C A$, in the cases of young patients) $(3,7,12-14)$. Only for 12 cases was the pre-operative CA125 value reported, and in 6 cases this was elevated (up to $551 \mathrm{U} / \mathrm{ml}$ ). The mean diameter of the cystic mass was $32 \mathrm{~mm}$ (ranging from 20 to $50 \mathrm{~mm}$ ).

In all selected cases, authors performed cyst excision using laparoscopic approach.

The first described surgical step was the introduction of a $10 \mathrm{~mm}$ laparoscope through an umbilical port, and then further ports (from $5 \mathrm{~mm}$ to $12 \mathrm{~mm}$ in diameter) were variably placed under-vision on the lower abdomen; variations included: the use of an accessory 12 $\mathrm{mm}$ port inserted into the left upper abdomen on the anterior axillary line on the surgeon's side (7) and 12 mm suprapubic port (3). Recognition of location of the lesion was usually easy due to large dimension of the cystic mass. Only in two cases, was intra-operative ultrasonography assistance necessary $(9,10)$. Having reached and incised the cystic cavity, a dark-brownish content flowed from the cyst. Chromo-tubation was performed by injecting indigo carmine dye into the uterine cavity through a uterine manipulator injector in 


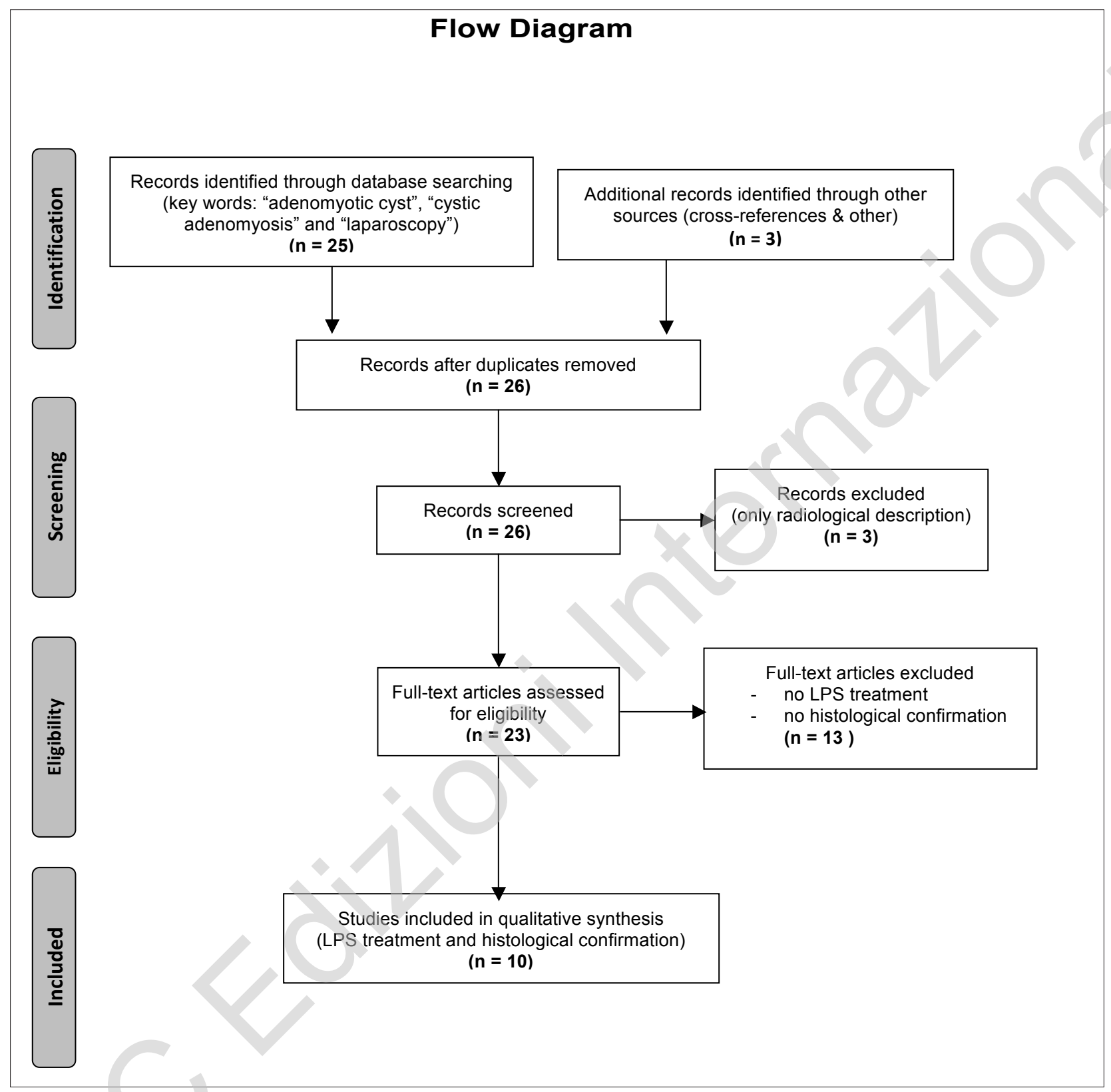

11 cases, to exclude abnormal direct communication between the cystic and uterine cavities and confirm patency of the fallopian tubes. Diluted vasopressin was injected into and around the nodule before resection, in 15 cases. Sharp and blunt dissection of the lesion was performed with a monopolar needle or scalpel, scissors and graspers.

After resection, the uterine defect was closed in a sero-muscular layer or in two or more layers (depending on the myometrial defect). The feasibility of sin- gle-incision laparoscopic surgery (SILS) and robot-assisted surgery were evaluated only for one patient (12, 14). Gasless laparoscopy was performed in two cases, using the subcutaneous abdominal wall-lift method (3). Hysteroscopy was performed as further evaluation in 6 cases to rule out any Müllerian anomaly and to look for a submucous component of the lesion.

Data on intra-operative blood loss, operative time and hospital stay are reported in Table 2. Comorbidities identified include uterine malformation (1 case), 
TABLE 1 - PRE-OPERATIVE DATA OF REVISED CASES.

\begin{tabular}{|c|c|c|c|c|c|c|}
\hline References & $\begin{array}{l}\text { n. cases } \\
\text { (age) }\end{array}$ & Symptoms & Definition & $\begin{array}{l}\text { Diagnostic } \\
\text { technique }\end{array}$ & $\begin{array}{l}\text { Lesion size } \\
(\mathrm{mm})\end{array}$ & $\begin{array}{l}\text { Pre-operative } \\
\text { medical therapies }\end{array}$ \\
\hline $\begin{array}{l}\text { Nabeshima, } \\
2003(9)\end{array}$ & $1(19)$ & $\begin{array}{l}\text { severe } \\
\text { dysmenorrhea }\end{array}$ & $\begin{array}{l}\text { cystic } \\
\text { adenomyoma }\end{array}$ & US, MRI & 30 & GnRH-a \\
\hline $\begin{array}{l}\text { Ball, } \\
2006 \text { (5) }\end{array}$ & $1(19)$ & $\begin{array}{l}\text { severe } \\
\text { dysmenorrhea }\end{array}$ & $\begin{array}{l}\text { cystic } \\
\text { adenomyosis }\end{array}$ & TVUS, HSC & 20 & NSAIDs, OC \\
\hline $\begin{array}{l}\text { Takeda, } \\
2007 \text { (3) }\end{array}$ & $2(20 ; 20)$ & $\begin{array}{l}\text { severe } \\
\text { dysmenorrhea }\end{array}$ & $\begin{array}{l}\text { juvenile cystic } \\
\text { adenomyoma }\end{array}$ & $\begin{array}{l}\text { TVUS, MRI, } \\
\text { HSG, DIP }\end{array}$ & 30 & NSAIDs, GnRH-a \\
\hline $\begin{array}{l}\text { Nabeshima, } \\
2008(10)\end{array}$ & $1(27)$ & $\begin{array}{l}\text { severe } \\
\text { dysmenorrhea }\end{array}$ & $\begin{array}{l}\text { cystic } \\
\text { adenomyoma }\end{array}$ & TVUS, MRI & 20 & $\begin{array}{l}\text { NSAIDs, OC, } \\
\text { GnRH-a }\end{array}$ \\
\hline $\begin{array}{l}\text { Akar, } \\
2010(12)\end{array}$ & $1(15)$ & $\begin{array}{l}\text { severe } \\
\text { dysmenorrhea, } \\
\text { intermittent right- } \\
\text { sided } \\
\text { periumbilical pain }\end{array}$ & $\begin{array}{l}\text { juvenile cystic } \\
\text { adenomyoma }\end{array}$ & & 47 & $\begin{array}{l}\text { aromatase } \\
\text { inhibitors, } \\
\text { progestins, OC, } \\
\text { GnRH-a }\end{array}$ \\
\hline $\begin{array}{l}\text { Takeuchi, } \\
2010 \text { (7) }\end{array}$ & $\begin{array}{l}9(19.3 \\
\text { mean })\end{array}$ & $\begin{array}{l}\text { severe } \\
\text { dysmenorrhea, } \\
\text { chronic pelvic } \\
\text { pain, dyspareunia }\end{array}$ & $\begin{array}{l}\text { juvenile cystic } \\
\text { adenomyoma }\end{array}$ & TVUS, MRI & 31.8 (mean) & $\begin{array}{l}\text { NSAIDs, OC, } \\
\text { GnRH-a }\end{array}$ \\
\hline $\begin{array}{l}\text { Chun, } \\
2011 \text { (11) }\end{array}$ & $1(19)$ & $\begin{array}{l}\text { severe } \\
\text { dysmenorrhea, } \\
\text { pelvic pain }\end{array}$ & $\begin{array}{l}\text { cystic } \\
\text { adenomyoma }\end{array}$ & MRI & 30 & NSAIDs, OC \\
\hline $\begin{array}{l}\text { Kriplani, } \\
2011 \text { (1) }\end{array}$ & $\begin{array}{l}4(18.5 \\
\text { mean })\end{array}$ & dismenorrhea & $\begin{array}{l}\text { cystic } \\
\text { adenomyoma }\end{array}$ & US, MRI & 45 (mean) & $\begin{array}{l}\text { NSAIDs, OC, } \\
\text { mifepristone }\end{array}$ \\
\hline $\begin{array}{l}\text { Cucinella, } \\
2013 \text { (13) }\end{array}$ & $1(25)$ & $\begin{array}{l}\text { severe } \\
\text { dysmenorrhea, } \\
\text { abdominal cramps }\end{array}$ & $\begin{array}{l}\text { juvenile cystic } \\
\text { adenomyosis }\end{array}$ & US, MRI & 50 & NSAIDs \\
\hline $\begin{array}{l}\text { Kumakiri, } \\
2013 \text { (14) }\end{array}$ & $1(20)$ & $\begin{array}{l}\text { severe } \\
\text { dysmenorrhea }\end{array}$ & $\begin{array}{l}\text { juvenile cystic } \\
\text { adenomyoma }\end{array}$ & US & 30 & N.S. \\
\hline
\end{tabular}

Note: $U S=$ ultrasound, $M R I=$ magnetic resonance images, $L P S=$ laparoscopy, $H S C=$ hysteroscopy, DIP $=$ drip infusion pyelography, NSAIDs = non-steroidal anti-inflammatory drugs, OC = oral contraceptive, GnRH-a = gonadotropin releasing hormoneagonist.

ovaric endometrioma (2 cases), and peritoneal endometriotic implants (7 cases). Mean operative time was 105 minutes (ranging from 66 to 234 minutes), and mean blood loss was $<42 \mathrm{ml}$ (ranging from 20 to $100 \mathrm{ml})$. In none of the cases reported was there any need for laparotomy intraoperative conversion. In all cases, histological exam described cystic walls lined with endometrial-type tissue. Time of follow-up ranged from 3 to 35.9 months, and, in $80 \%$ of treated cases, a painless postoperative course was referred, often with complete resolution of symptoms. During the post-operative period, there was no recurrence of cystic lesions or adenomyosis.

Reproductive outcome was examined in 7 cases, and 4 pregnancies were confirmed after laparoscopic cystectomy. 


\section{G. Calagna et al.}

\section{Discussion and conclusions}

Diffuse adenomyosis usually shows blood filled cystic spaces, $<5 \mathrm{~mm}$ in diameter and scattered throughout the myometrium (15). The possibility of a single cystic mass within the myometrium as a rare variant of focal adenomyosis is a recent finding (16), and, to date, is not a well-known phenomenon. Diagnosis is suspected when the severity of symptoms (unresponsive to medical therapy) and early onset are associated to images (US, TC, MRI) that show a cystic lesion within the myometrium, with maximum diameter $\geq 10 \mathrm{~mm}$ (1).

Although etiology is currently unclear, it is generally agreed that cystic adenomyosis in adult women originates from the disruption of the uterine junctional-zone architecture, as in the diffuse variety; in this way, hemorrhagic cystic spaces are created by menstrual bleeding in the ectopic endometrial tissue infiltrating the uterine wall (8). Indeed, the pathogenesis of juvenile cystic adenomyosis (JCA) is still doubtful. Based on symptom onset, some authors (16-18) suggest a derivation from a congenital defect of the development of the Müllerian duct, which leads to non-communicating accessory cavitated uterine mass (also called ACUM), lined by endometrium and with an otherwise normal uterus (18).

According to Takeuchi's criteria (7), diagnosis of JCA is highly probable in women aged $\leq 30$, presenting a solitary uterine cyst measuring $\geq 10 \mathrm{~mm}$, clearly independent of the uterine cavity and associated with severe dysmenorrhea that occurs soon after menarche.

As shown by review data, symptoms are insufficiently relieved by medical treatment, and recurrence and worsening of dysmenorrhea is typically noticed when drug administration is interrupted. First-line diagnostic method of suspected cystic adenomyosis is pelvic ultrasound $(5,19)$. MRI should be reserved as adjunctive investigation, in order to differentiate some confounding appearances $(20,21)$. Diagnostic hysteroscopy should be undertaken to evaluate the shape of uterine cavity and confirm non-communication of cystic lesion with the endometrial cavity (22-24).

Although there is a lack of consensus on treatments for adenomyosis, recent evidence promotes the use of conservative, uterine-sparing surgery, to increase fertility preservation and improve patient's quality of life (25). Certainly, in cases of cystic adenomyosis affecting young patients, conservative surgery is mandatory and cystectomy should be preferred (13).
With the progressive diffusion of laparoscopic surgery in gynecology and the consequent improvement of laparoscopic surgical performances (26), in recent years laparoscopic cystectomy has been adopted as the alternative approach in the surgical management of cystic adenomyosis.

Use of laparoscopic approach adds the advantage of minimally invasive surgery (10) and allows careful inspection of entire abdominopelvic cavity to identify and treat other lesions $(27,28)$.

According to the data of our review, laparoscopy seems to have several benefits over traditional abdominal technique, such as minimally invasive approach, low blood loss, short hospitalization, and quicker return to daily activities (29). Some Authors state that laparoscopic removal of large cystic masses might be more challenging compared to open surgery, with limited exposure of the lesion and difficult totally excision of the disease (5). Nevertheless, in none of the cases reported was intraoperative conversion to laparotomy necessary, nor was there post-operative recurrence of the disease. Clearly, these procedures need a skilled laparoscopic surgeon and a dedicated medical team.

The role of suppressive hormonal therapy after cystectomy to prevent a clinical and/or anatomical recurrence is not clear. Despite the usefulness of a long-term oral contraceptive (OC) regimen after conservative surgery for the prevention of ovarian endometrioma recurrence being demonstrated in recent studies $(30,31)$, there is no clear evidence of its use in cystic adenomyosis recurrence prevention. Further studies are required to assess potential benefits.

With regard to the advantages of pre-operative use of GnRH-a therapy, reduction of symptoms, reduction of uterine vascularity, correction of anemia and reduction of operative bleeding are reported (32). In contrast, the indistinct demarcation between normal tissue and cystic tumor may increase the risk of incomplete excision and consequent early relapse; thus, some authors suggest performing a wide resection of the cystic mass to remove surrounding fibrosis and prevent relapse $(1,5,16)$.

Reproductive outcome after laparoscopic cystectomy in women who desire to become pregnant seems to be good. However, most of the studies reported were not primarily designed to define this issue and larger series are needed to prove any link between subfertility and cystic adenomyosis.

In conclusion, although rare, cystic adenomyosis must be considered in young women as an uncommon cause for both primary and secondary severe dysmen- 
TABLE 2 - INTRA-OPERATIVE AND POST-OPERATIVE DATA OF REVISED CASES.

\begin{tabular}{|c|c|c|c|c|c|c|c|}
\hline References & Surgery & $\begin{array}{l}\text { Operative } \\
\text { time } \\
\text { (min) }\end{array}$ & $\begin{array}{l}\text { Blood } \\
\text { loss (ml) }\end{array}$ & $\begin{array}{l}\text { Hospital } \\
\text { stay } \\
\text { (days) }\end{array}$ & Comorbidities & Histology & $\begin{array}{l}\text { Clinical } \\
\text { outcome }\end{array}$ \\
\hline $\begin{array}{l}\text { Nabeshima, } \\
2003 \text { (9) }\end{array}$ & $\begin{array}{l}\text { LPS } \\
\text { cystectomy }\end{array}$ & 234 & $<100$ & 4 & n.s. & $\begin{array}{l}\text { Cystic wall lined } \\
\text { with } \\
\text { endometrial-type } \\
\text { epithelium }\end{array}$ & $\begin{array}{l}\text { Symptoms } \\
\text { resolution }\end{array}$ \\
\hline $\begin{array}{l}\text { Ball, } \\
2006 \text { (5) }\end{array}$ & $\begin{array}{l}\text { Diagnostic } \\
\text { HSC; LPS } \\
\text { cystectomy }\end{array}$ & 90 & $<20$ & 1 & arcuate uterus & $\begin{array}{l}\text { Cystic cavity } \\
\text { with endometrial } \\
\text { and stromal } \\
\text { lining }\end{array}$ & $\begin{array}{l}\text { Symptoms } \\
\text { resolution }\end{array}$ \\
\hline $\begin{array}{l}\text { Takeda, } \\
2007 \text { (3) }\end{array}$ & $\begin{array}{l}\text { Gasless LPS } \\
\text { cystectomy }\end{array}$ & 79,67 & $\begin{array}{l}<20 \\
<50\end{array}$ & 3 & none & $\begin{array}{l}\text { Cystic cavity } \\
\text { with endometrial } \\
\text { tissue lining }\end{array}$ & $\begin{array}{l}\text { Symptoms } \\
\text { resolution }\end{array}$ \\
\hline $\begin{array}{l}\text { Nabeshima, } \\
2008 \text { (10) }\end{array}$ & $\begin{array}{l}\text { LPS } \\
\text { cystectomy }\end{array}$ & 190 & n.s. & 4 & $\mathrm{n}$ & $\begin{array}{l}\text { Cystic wall lined } \\
\text { with } \\
\text { endometrial-type } \\
\text { epithelium and } \\
\text { stroma }\end{array}$ & $\begin{array}{l}\text { Symptoms } \\
\text { resolution }\end{array}$ \\
\hline $\begin{array}{l}\text { Akar, } \\
2010 \text { (12) }\end{array}$ & $\begin{array}{l}\text { Robotic } \\
\text { cystectomy }\end{array}$ & n.s. & n.s. & n.s. & & $\begin{array}{l}\text { Uterine cystic } \\
\text { adenomyoma }\end{array}$ & n.s. \\
\hline $\begin{array}{l}\text { Takeuchi, } \\
2010 \text { (7) }\end{array}$ & $\begin{array}{l}\text { LPS } \\
\text { cystectomy }\end{array}$ & $\begin{array}{l}78 \\
\text { (mean) }\end{array}$ & $\begin{array}{l}33.6 \\
\text { (mean) }\end{array}$ & n.s. & $\begin{array}{l}\text { ovaric } \\
\text { endometrioma } \\
(1 \text { case }) \\
\text { peritoneal } \\
\text { endometriosis } \\
\text { ( } 5 \text { cases) }\end{array}$ & $\begin{array}{l}\text { Cystic wall lined } \\
\text { with } \\
\text { endometrial-type } \\
\text { glands and } \\
\text { stroma; }\end{array}$ & $\begin{array}{l}\text { Improving of } \\
\text { symptoms }\end{array}$ \\
\hline $\begin{array}{l}\text { Chun, } \\
2011 \text { (11) }\end{array}$ & $\begin{array}{l}\text { LPS } \\
\text { cystectomy }\end{array}$ & $n$ & & n.s. & n.s. & $\begin{array}{l}\text { Cystic cavity } \\
\text { lined by } \\
\text { endometrial } \\
\text { tissue } \\
\text { (epithelium and } \\
\text { stroma) }\end{array}$ & n.s. \\
\hline $\begin{array}{l}\text { Kriplani, } \\
2011 \text { (1) }\end{array}$ & $\begin{array}{l}\text { HSC; LPS } \\
\text { cystectomy }\end{array}$ & $\begin{array}{l}66.25 \\
\text { (mean) }\end{array}$ & n.s. & $\begin{array}{l}1.5 \\
\text { (mean) }\end{array}$ & $\begin{array}{l}\text { ovaric } \\
\text { endometrioma } \\
(1 \text { case })\end{array}$ & $\begin{array}{l}\text { Endometrial } \\
\text { tissue } \\
\text { surrounded by } \\
\text { myometrium }\end{array}$ & $\begin{array}{l}\text { Improving of } \\
\text { symptoms }\end{array}$ \\
\hline $\begin{array}{l}\text { Cucinella, } \\
2013 \text { (13) }\end{array}$ & $\begin{array}{l}\text { LPS } \\
\text { cystectomy }\end{array}$ & 70 & $<20 \mathrm{ml}$ & 2 & $\begin{array}{l}\text { ovaric } \\
\text { endometriotic } \\
\text { implants and } \\
\text { peritoneal } \\
\text { implants }\end{array}$ & $\begin{array}{l}\text { Cystic wall lined } \\
\text { with endometrial } \\
\text { epithelium and } \\
\text { stroma }\end{array}$ & $\begin{array}{l}\text { Improving of } \\
\text { symptoms }\end{array}$ \\
\hline $\begin{array}{l}\text { Kumakiri, } \\
2013 \text { (14) }\end{array}$ & $\begin{array}{l}\text { SILS } \\
\text { cystectomy }\end{array}$ & 70 & 30 & 2 & n.s. & $\begin{array}{l}\text { Endometrial } \\
\text { tissue (glands } \\
\text { and stroma) } \\
\text { lining the inner } \\
\text { surface }\end{array}$ & $\begin{array}{l}\text { Improving of } \\
\text { symptoms }\end{array}$ \\
\hline
\end{tabular}

Note: $L P S=$ laparoscopy, HSC = hysteroscopy, SILS = single incision laparoscopic surgery. 


\section{G. Calagna et al.}

orrhea. Appropriate imaging study should be carried out before surgery to guide the surgeon during opera- tive time. Laparoscopic cystectomy is the option of choice, with excellent medium-term results.

\section{References}

1. Kriplani A, Mahey R, Agarwal N, Bhatla N, Yadav R, Singh MK. Laparoscopic Management of Juvenile Cystic Adenomyoma: Four Cases. J Minim Invasive Gynecol. 2011; 18:343-438.

2. Farquhar C, Brosens I. Medical and surgical management of adenomyosis. Best Practice \& Research Clin Obstet Gynaecol. 2006;20(4):603-616.

3. Takeda A, Sakai K, Mitsui T, Nakamura H. Laparoscopic management of juvenile cystic adenomyoma of the uterus: report of two cases and review of the literature. J Minim Invasive Gynecol. 2007;14:370-374.

4. Slezak P, Tillinger KG. The incidence and clinical importance of hysterographic evidence of cavities in the uterine wall. Radiology. 1976;118:581-6.

5. Ball E, Ganji M, Janik G, Koh C. Laparoscopic resection of cystic adenomyosis in a teenager with arcurate uterus. Gynecol Surg. 2009;6:367-370.

6. Bergeron C, Amant F, Ferenczy A. Pathology and physiopathology of adenomyosis. Best Prac Res Clin Obstet Gynaecol. 2006;20(4):511-521.

7. Takeuchi H, Kitade M, Kikuchi I, Kumakiri J, Kuroda K, Jinushi M. Diagnosis, laparoscopic management and histopathological findings of juvenile cystic adenomyoma: a review of nine cases. Fertil Steril. 2010;94:862-868.

8. Dogan E, Gode F, Saatli B, Secil M. Juvenile cystic adenomyosis mimicking uterine malformation: a case report. Arch Gynecol Obstet. 2008;278:593-595.

9. Nabeshima H, Takashi Murakami T, Terada Y, Noda T, Yaegashi N, Okamura K. Total laparoscopic surgery of cystic adenomyoma under hydro-ultrasonographic monitoring. J Am Assoc Gynecol Laparosc. 2003;10(2):195-199.

10. Nabeshima H, Murakami T, Nishimoto M, Sugawara N, Sato N. Successful total laparoscopic cystic adenomyomectomy after unsuccessful open surgery using transtrocar ultrasonographic guiding. J Minim Invasive Gynecol. 2008;15(2):227-230.

11. Chun SS, Hong DG, Seong WJ, Choi MH, Lee TH. Juvenile cystic adenomyoma in a 19-year-old woman: a case report with a proposal for new diagnostic criteria. J Laparoendosc Adv Surg Tech A. 2011;21(8):771-774.

12. Akar ME, Leezer KH, Yalcinkaya TM. Letter to the editor: Robot-assisted laparoscopic management of a case with juvenile cystic adenomyoma. Fertil Steril. 2010;94(3):e55-e56.

13. Cucinella G, Billone V, Pitruzzella I, Lo Monte A, Palumbo VD, Perino A. Adenomyotic cyst in a 25 -year-old woman: case report. J Minim Invasive Gynecol. 2013;20(6):894-898.

14. Kumakiri J, Kikuchi I, Sogawa Y, Jinushi M, Aoki Y, Kitade M, Takeda S. Single-incision laparoscopic surgery using an articulating monopolar for juvenile cystic adenomyoma. Minim Invasive Ther Allied Technol. 2013;22(5):312-315.

15. Tamai K, Togashi K, Ito T, Morisawa N, Fujiwara T, Koyama T. MR imaging findings of adenomyosis: correlation with histopathologic features and diagnostic pitfalls. RadioGraphics. 2005;25:21-40.

16. Tamura M, Fukaya T, Takaya R, Ip CW, Yajima A. Juvenile adenomyotic cyst of the corpus uteri with dysmenorrhea. Tohoku J Exp Med. 1996;178:339-44.

17. Potter DA, Schenken RS. Noncommunicating accessory uterine cavity. Fertil Steril. 1998;70:1165-6.

18. Acien P, Acien M, Fernandez F, Jose Mayol M, Aranda I. The cavitated accessory uterine mass: a mullerian anomaly in women with an otherwise normal uterus. Obstet Gynecol. 2010;116:1101-1109.

19. Ho ML, Ratts V, Merritt D. Adenomyotic cyst in an adolescent girl. J Pediatr Adolesc Gynecol. 2009;22:e33-e38.

20. Jain N, Goel S. Cystic adenomyoma simulates uterine malformation: A diagnostic dilemma: Case report of two unusual cases. J Hum Reprod Sci. 2012;5(3):285-288.

21. Troiano RN, Flynn SD, McCarthy S. Cystic adenomyosis of the uterus: MRI. J Magn Reson Imaging. 1998;8:1198-1202.

22. Perino A, Calagna G, Fiorella G, Vitrano G, Rimi C, Marci R, Cucinella G. Long and fluctuating bone fragments in uterine isthmus: A curious feature of true osseous metaplasia. J Obstet Gynaecol Res. 2014;40(6):1819-1822.

23. Di Spiezio Sardo A, Bettocchi S, Spinelli M, Guida M, Nappi L, Angioni S, Sosa Fernandez LM, Nappi C. Review of new office-based hysteroscopic procedures 2003-2009. J Minim Invasive Gynecol. 2010;17(4):436-448.

24. Perino A, Forlani F, Casto A, Calì G, Calagna G, Rotolo S, Cucinella G. Septate uterus: nosographic overview and endoscopic treatment. Gynecological Surgery. 2011;11(2):129138.

25. Grimbizis GF, Mikos T, Tarlatzis BC. Uterus-sparing operative treatment for adenomyosis. Fertil Steril. 2014;101:47287.

26. Cucinella G, Granese R, Calagna G, Somigliana E, Perino A. Parasitic myomas after laparoscopic surgery: an emerging complication in the use of morcellator? Description of four cases. Fertil Steril. 2011;96(2):e90-96.

27. Wolthuis AM, Tomassetti C. Multidisciplinary laparoscopic treatment for bowel endometriosis. Best Practice \& Research Clinical Gastroenterology. 2014;28(1):53-67.

28. Cucinella G, Granese R, Calagna G, Candiani M, Perino A. Laparoscopic treatment of diaphragmatic endometriosis causing chronic shoulder and arm pain. Acta Obstet Gynecol Scand. 2009;88(12):1418-1419.

29. DeSimone C, Ueland FR. Gynecologic Laparoscopy. Surg Clin N Am. 2008:88:319-341.

30. Seracchioli R, Mabrouk M, Manuzzi L, Vicenzi C, Frasca`C, Elmakky A, Venturoli S. Post-operative use of oral contraceptive pills for prevention of anatomical relapse or symptom recurrence after conservative surgery for endometriosis. Human Reprod. 2009; 24:2729-2735. 
Surgical management of cystic adenomyosis. Why the laparoscopic approach is preferable?

31. Cucinella G, Granese R, Calagna G, Svelato A, Saitta S, Tonni G, De Franciscis P, Colacurci N, Perino A. Oral contraceptives in the prevention of endometrioma recurrence: does the different progestins used make a difference? Arch Gynecol Ob- stet. 2013; 288(4):821-827.

32. Fedele L, Bianchi S, Frontino G. Hormonal treatments for adenomyosis. Best Pract Res Clin Obstet Gynaecol. 2008;22(2):333-339. 